\title{
A LÓGICA INDUSTRIAL DE MATO GROSSO DO SUL: ALGUMAS REFLEXÕES A PARTIR DOS INCENTIVOS FISCAIS
}

\author{
THE INDUSTRIAL LOGIC OF MATO GROSSO DO SUL: SOME \\ REFLECTIONS FROM THE TAX INCENTIVES
}

\section{LA LÓGICA INDUSTRIAL DE MATO GROSSO DO SUL: ALGUNAS REFLEXIONES A PARTIR DE LOS INCENTIVOS FISCALES}

\author{
Patrícia Pogliesi Paz \\ Doutoranda em Geografia. Universidade Federal da Grande Dourados \\ ppatipaz90@gmail.com \\ Eliana Lamberti \\ Doutora em Economia do Desenvolvimento. \\ Docente da Universidade Estadual de Mato Grosso do Sul \\ eliana@uems.br
}

\section{RESUMO}

Este artigo objetiva apreender a realidade industrial de Mato Grosso do Sul por meio da política de incentivos fiscais. De modo específico, busca-se: relacionar as premissas do planejamento público, dos polos de desenvolvimento e da industrialização; compreender as especificidades dos polos de desenvolvimento industrial desse estado; sintetizar a evolução da política de incentivos à indústria e sua materialização, a partir de alguns dados selecionados, em período recente. Do ponto de vista metodológico, realizou-se a revisão bibliográfica baseada na literatura relacionada ao tema. A base empírica foi construída a partir de dados secundários. O território de Mato Grosso do Sul é contemplado pela política industrial por meio do Programa MS-EMPREENDEDOR (regulamentado por Lei Complementar), e dispõe ainda de incentivos de créditos federais oferecidos por instituições bancárias (BNDES) e do Fundo Constitucional de Financiamento do Centro-Oeste (FCO), além dos incentivos municipais. No período de 2010 a 2015, 406 indústrias receberam incentivos para a implantação ou ampliação de suas plantas industriais e geraram 52.824 empregos. Os municípios sul-mato-grossenses

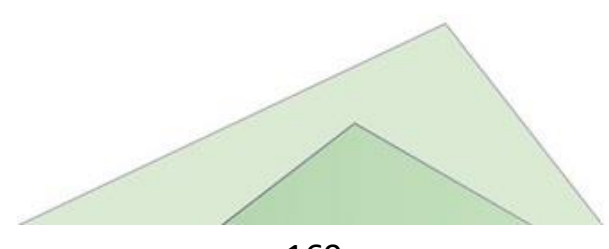


que mais tiveram indústrias incentivadas, no referido período, foram os seguintes: Campo Grande, Três Lagoas, Paranaíba, Dourados, Aparecida do Taboado, Cassilândia, Terenos, Bataguassu, Naviraí, São Gabriel do Oeste, Corumbá, Nova Andradina, Sidrolândia e Porto Murtinho.

Palavras-Chave: Planejamento público; Política de Industrialização; Guerra fiscal; Dinâmica industrial.

\begin{abstract}
This article aims to capture the industrial reality of Mato Grosso do Sul through the policy of tax incentives. Specifically, the aim is to: relate the premises of public planning, development and industrialization poles; understand the specificities of the industrial development poles of the state; synthesize the evolution of the incentives policy to the industry and its materialization, from some selected data, in the recent period. From a methodological point of view, it was carried out a bibliographic review based on the literature related to the topic. The empirical basis was built from secondary data. The territory of Mato Grosso do Sul is covered by industrial policy through the MSEMPREENDEDOR Program (regulated by Complementary Law), and also has federal credit incentives offered by banking institutions (BNDES) and the Fundo Constitucional de Financiamento do Centro-Oeste (FCO), in addition to municipal incentives. In the period from 2010 to 2015, 406 industries received incentives for the implantation or expansion of their industrial plants and have generated 52.824 jobs, in this period. In the state, the town halls that had the most incentive industries in that period were: Campo Grande, Três Lagoas, Paranaíba, Dourados, Aparecida do Taboado, Cassilândia, Terenos, Bataguassu, Naviraí, São Gabriel do Oeste, Corumbá, Nova Andradina, Sidrolândia and Porto Murtinho.
\end{abstract}

Key words: Public planning; Industrialization Policy; Fiscal war; Industrial dynamics.

\title{
RESUMEN
}

Este articulo tiene como objetivo detectar la realidad industrial de Mato Grosso do Sul por medio de la política de incentivos fiscales. De manera específica, se busca: relacionar las primicias del planeamiento público, de los polos de desarrollo y de la industrialización; comprender las especificidades de los polos de desarrollo industrial del estado; sintetizar la evolución de la política de incentivos a la indústria y su materialización, apartir de algunos dados seleccionados, en la actualidad. Del punto de vista metodológico, realizamos la revisión bibliográfica basada en la literatura




relacionada al tema. La base empirica fue construida apartir de dados secundarios. El territorio de Mato Grosso do Sul es contemplado por la política industrial por medio del Programa MS-EMPREENDEDOR (reglamentado por Ley Complementar), y dispone todavia de incentivos de creditos federales ofrecidos por instituciones bancárias (BNDES) e del Fondo Constitucional del Financiamiento del Centro-Oeste (FCO), además de los incentivos municipales. En el periodo de 2010 a 2015, 406 indústrias recibieron incentivos para la implantación o ampliación de sus plantas industriales y generaron en ese período, 52.824 empleos. Los municípios del estado que tuvieron más industrias con incentivos en el período mencionado, fueron las siguientes: Campo Grande, Três Lagoas, Paranaíba, Dourados, Aparecida do Taboado, Cassilândia, Terenos, Bataguassu, Naviraí, São Gabriel do Oeste, Corumbá, Nova Andradina, Sidrolândia e Porto Murtinho.

Palabras-Claves: Planeamiento público; Política de Industrialización; Guerra fiscal; Dinamica industrial.

\section{INTRODUÇÃO}

O processo de industrialização brasileiro foi lento e tardio, pois começou com um atraso de mais de um século em relação aos países líderes da Revolução Industrial. Mesmo após deixar de ser colônia de Portugal, o Brasil ainda manteve suas raízes tipicamente agrárias até meados do século XIX. Esse processo de industrialização, e, consequentemente, as alterações das características de uma sociedade rural e agrária para uma urbana e industrial, iniciou-se na segunda metade do século XIX, ganhou impulso nas primeiras décadas do século XX e teve um salto no período pós-Segunda Guerra Mundial. Tal processo apresentou várias fases de declínio e crescimento da atividade industrial, mas o traço comum a todas elas foi a presença, em maior ou menor grau, de ações do Estado impulsionando a formação e a consolidação do parque industrial brasileiro (MENDONÇA, 2010).

Desde o pós-Segunda Guerra Mundial até a crise mundial de meados dos anos setenta, os países capitalistas tiveram um elevado crescimento econômico, definido pelo historiador Eric Hobsbawm como "A Era de Ouro do Capitalismo" ou "Os anos Dourados". De acordo com o autor, essas décadas registraram "extraordinário

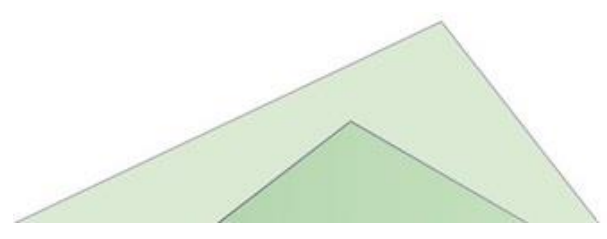


crescimento econômico e transformação social, anos que provavelmente mudaram de maneira mais profunda a sociedade humana que qualquer outro período de brevidade comparável". O referido autor destaca que: "a Era de Ouro foi um fenômeno mundial, embora a riqueza geral jamais chegasse à vista da maioria da população do mundo" (HOBSBAWM, 1995, p. 15, 255).

Para Ferraz, De Paula e Kupfer (2002), o objetivo clássico almejado pela política industrial é a promoção da atividade produtiva, no sentido de alcançar estágios de desenvolvimento superiores aos antecedentes em um determinado espaço nacional. Por conseguinte, sob o prisma conceitual, política industrial pode ser entendida como o "conjunto de incentivos e regulações associadas a ações públicas, que podem afetar a alocação inter e intraindustrial de recursos, influenciando a estrutura produtiva e patrimonial, a conduta e o desempenho dos agentes econômicos em um determinado espaço nacional” (FERRAZ; DE PAULA; KUPFER, 2002, p. 545).

Dentre as principais características da industrialização tardia do Brasil, ocorrida ao longo do século $\mathrm{XX}$, destaca-se o processo de concentração geográfica na região Sudeste, especialmente no estado de São Paulo, o que acabou reproduzindo uma série de desigualdades regionais no território brasileiro (SILVA, 2008).

A partir das décadas de 1940 e 1950, Diniz (1995) aponta para o início de um movimento de desconcentração geográfica da produção: com o movimento da fronteira agropecuária no sentido do sul do Brasil em direção às regiões Centro-Oeste e Norte e às faixas de cerrados do Nordeste. Os anos 1970 marcaram uma mudança na localização industrial brasileira com efeitos significativos no setor de serviços e comércio.

Conforme Diniz (1995), o processo de desconcentração industrial do estado de São Paulo para outras regiões do país, resultou de diversos fatores, em especial de: a) deseconomias de aglomeração ${ }^{1}$ na área metropolitana de São Paulo e criação de economias de aglomeração em vários outros centros urbanos e regiões; b) ação do Estado

1 A partir do momento em que a metrópole passa a apresentar desvantagens, que do ponto de vista das indústrias superam as vantagens, teríamos as deseconomias de aglomeração, pois tais desvantagens levam as indústrias a buscar outros locais mais vantajosos para se instalarem. 
em termos de investimento direto, incentivos fiscais e construção da infraestrutura; c) busca de recursos naturais, por meio da expansão das fronteiras agrícola e mineral, com reflexos na localização de um conjunto de atividades industriais; d) unificação do mercado, potencializada pelo incremento da infraestrutura de transportes e comunicações, com efeitos sobre a competição interindustrial e a localização.

A partir dessa dinâmica, é possível compreender o processo de (agro)industrialização do estado de Mato Grosso do Sul (MS) e seus contornos, especialmente a partir do século XXI, considerando sua localização tanto do ponto de vista da geografia física como econômica na divisão nacional do trabalho. O estado de Mato Grosso do Sul é constituído por uma área territorial que atinge uma extensão de $357.145,4 \mathrm{Km}^{2}$, que se estende até as fronteiras internacionais com as Repúblicas do Paraguai e da Bolívia na sua parte sul e sudoeste, onde é banhado pela bacia do Rio Paraguai. Na fronteira leste, norte e nordeste, é banhado pela bacia do Rio Paraná e seus afluentes, fazendo divisa com cinco estados brasileiros: Paraná, São Paulo, Minas Gerais, Goiás e Mato Grosso. A organização político-administrativa é constituída por 79 municípios com centros urbanos administrativos. De acordo com o Instituto Brasileiro de Geografia e Estatística (IBGE), em 2010, a população residente na área urbana correspondia a $85,64 \%$ e, em 2020, a população estimada é de 2,8 milhões de habitantes.

Para contemplar o objetivo geral (apreender a realidade industrial de Mato Grosso do Sul por meio da política de incentivos fiscais), é necessário compreender a "ação do estado em termos de investimento direto, incentivos fiscais e construção da infraestrutura" (DINIZ, 1995, p. 7). Portanto, de modo específico e complementar, as próximas páginas buscam: relacionar as premissas do planejamento público, dos polos de desenvolvimento e da industrialização a partir de conceitos e referenciais seminais; compreender as especificidades dos polos de desenvolvimento industrial do estado sulmato-grossense por meio de documentos de planejamento; e, por meio da síntese da evolução da política de incentivos à indústria e alguns dados selecionados, discutir a materialização da dinâmica industrial sul-mato-grossense. 
Destaca-se que essa temática tem sido objeto de pesquisa de diversas áreas (especialmente da geografia econômica), porém não se esgotam as problemáticas advindas do contexto complexo e dinâmico do capitalismo, especialmente na segunda década do século XXI. Dessa forma, justifica-se o recorte temporal (pós-2010) da análise empírica proposta por se constituir em um esforço de atualizar a discussão em termos de políticas de incentivos e seus resultados práticos na configuração industrial. Portanto, a ênfase recai sobre os incentivos institucionalizados de 2010 a 2015 e como reverberaram em alguns dados nos anos subsequentes.

\section{PLANEJAMENTO PÚBLICO E A “GUERRA FISCAL"}

A discussão em torno do conceito de desenvolvimento é ampla e envolve várias áreas do conhecimento. Para fins das reflexões propostas neste texto, adota-se a perspectiva de que por desenvolvimento deve-se entender transformações qualitativas e estruturais no conjunto da economia que somente ocorrem com investimento, inovações técnicas, progresso tecno-científico e educação - isto é, capital humano capaz de desenvolver uma atividade de forma eficiente, bem como aprender novos métodos e procedimentos. A literatura sobre a temática do desenvolvimento é consensual sobre o papel que o segmento industrial desempenha nessa dinâmica, uma vez que é o lócus do progresso técnico, da agregação de valor e da oferta dos melhores postos de trabalho.

De acordo com Souza (2008), em um contexto de ascensão das políticas regionais no Brasil, especialmente, a partir da segunda metade da década de 1960 e década de 1970:

a teoria dos polos de desenvolvimento parecia idealmente adequada para enfrentar a questão das disparidades regionais, assim como a excessiva concentração (de pessoas, atividades e capital) em áreas metropolitanas. De acordo com os pressupostos da polarização, a inversão em infraestrutura, os subsídios ao desenvolvimento e outras formas da intervenção pública poderiam concentrar-se em poucos centros com potencialidades de crescimento, localizados, porém, em áreas atrasadas ou próximo delas. As economias de aglomeração gerariam um crescimento nos centros escolhidos e, finalmente,

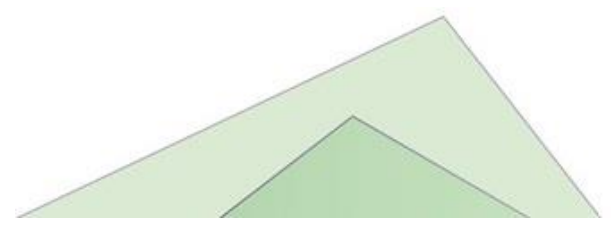




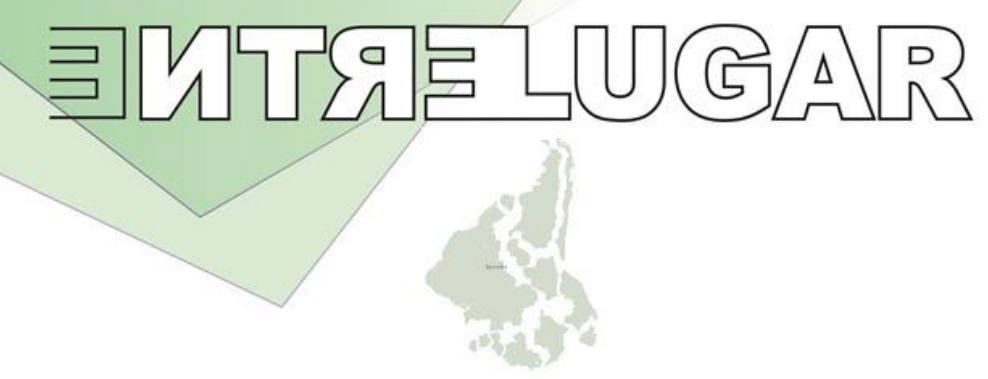

fluiriam alguns efeitos de difusão benéficos até as áreas polarizadas. Assim, se promoveria a eficiência econômica e a equidade regional, as regiões atrasadas se desenvolveriam e os fluxos de pessoas, bens e capitais, que de outro modo se dirigiriam para as áreas metropolitanas congestionadas, se desviariam até seletivos centros regionais (SOUZA, 2008, p. 16-17).

A partir do momento em que o centro dinâmico industrial passa a apresentar desvantagens que superam as vantagens, tem-se as deseconomias de aglomeração, pois tais condições levam as indústrias a buscar outros locais para se instalarem. De acordo com Sampaio (2015),

[...] se existem as economias de aglomeração, existem também as deseconomias de aglomeração. Para boa parte dos ramos da indústria, por exemplo, as grandes cidades e regiões metropolitanas apresentam algumas desvantagens como: escassez e alto preço da terra, e maior custo de vida (necessidade de se pagar maiores salários) se comparado às cidades médias. Há também o fato de que muitas indústrias são poluentes, o que é cada vez menos tolerado nas grandes cidades (questões legais, danos de imagem) (SAMPAIO, 2015, p. 491).

De acordo com Sunkel e Paz (1970), o desenvolvimento da indústria foi durante algum tempo considerado como sinônimo de desenvolvimento econômico:

El desarrollo de la industria fue el aspecto más llamativo y dinámico tanto en los países avanzados como en los subdesarrollados, de manera tal que durante algún tiempo el desarrollo industrial se consideró incluso sinónimo o de desarrollo económico. No es un proceso que se haya dado necesariamente y en forma espontánea, ni ha sido por lo general gradual ni armónico; se tradujo de hecho en la expansión acelerada de una parte'del sistema económico y de esa manera impulsó un cambio estructural en dicho sistema (SUNKEL; PAZ, 1970, p. 25-26).

No território brasileiro, essas influências teóricas acrescidas da ampliação da autonomia fiscal dos estados e municípios brasileiros a partir da Constituição Federal de 1988 e da concepção de que a industrialização é o caminho para o desenvolvimento econômico fizeram com que municípios e as Unidades da Federação menos industrializados passassem a estimular a instalação de indústrias por meio de incentivos fiscais, de modo a atrair investimentos e gerar riqueza e renda.

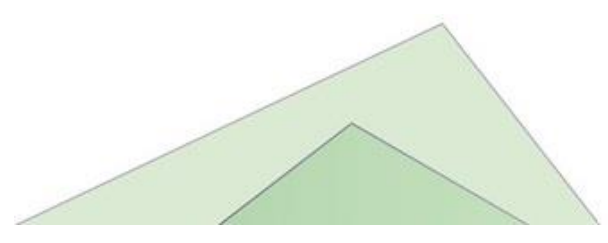


Essa estratégia propiciou o acirramento de disputas entre diversas instâncias de planejamento para verificar qual ofereceria melhores incentivos para a instalação fabril.

A concessão de benefícios fiscais pelos estados visa gerar emprego e renda para a população e o aumento do valor acrescentado ao longo das cadeias produtivas, devido à maior transformação industrial, e ainda ao aumento da receita tributária futura. No entanto, a "guerra fiscal" entre estados e municípios causa efeitos negativos, na medida em que gera conflitos entre os estados, aumentando a concorrência entre os mesmos. Os autores Ferreira (2000) e Lengruber (1999) explicam que:

Esta "Guerra" gera conflitos na Federação. No curto prazo, o Estado que deflagra a guerra se beneficia. No longo prazo, a generalização do conflito faz com que os ganhos iniciais desapareçam, pois os incentivos fiscais perdem o seu poder de estímulo e se transformam em meras renúncias de arrecadação; além disso, os Estados que mais perderão serão os mais pobres, que, curiosamente, são os que mais concedem incentivos, uma vez que, paralelo ao desenvolvimento atraído para o seu território, desencadeia-se a contrapartida natural, ou seja, o crescimento das demandas por serviços públicos, tais como: educação, saúde, transporte, segurança, saneamento básico, entre outras despesas provenientes do crescimento populacional e da elevação da renda per capita (FERREIRA, 2000; LENGRUBER, 1999 apud NASCIMENTO, 2008, p. 680).

Para Santos e Silveira (2001), isso se traduziu em uma guerra dos lugares no Brasil e na busca das empresas por "lugares produtivos":

\begin{abstract}
Fala-se hoje muito em guerra fiscal, na medida em que a disputa de estados e municípios pela presença de empresas e a busca de empresas de lugares para se instalar lucrativamente é vista, sobretudo, nos seus aspectos fiscais. A realidade é que, do ponto de vista das empresas, o mais importante mesmo é a guerra que elas empreendem para fazer com que os lugares, isto é, os pontos onde desejam instalar-se ou permanecer, apresentem um conjunto de circunstâncias vantajosas do seu ponto de vista. Trata-se, na verdade, de uma busca de lugares "produtivos" (SANTOS; SILVEIRA, 2001, p. 296).
\end{abstract}

Contudo, os governantes estaduais, para justificarem a sua adesão à guerra fiscal, afirmam que tal procedimento estimula aumentos na receita do Imposto sobre Circulação de Mercadorias e Serviços (ICMS). Este aumento, no curto prazo, seria fruto do efeito multiplicador, a partir da instalação de uma nova empresa no Estado, ou seja, o

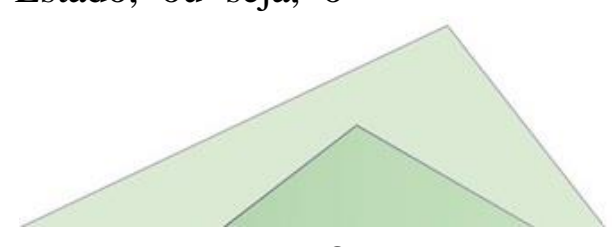


crescimento indireto desencadeado pela implantação de uma nova planta. No longo prazo, o crescimento da receita seria fruto do recolhimento do ICMS pela empresa, quando do término da renúncia do recolhimento do tributo (NASCIMENTO, 2008).

Ademais, o contexto industrial atual é pautado na lógica das cadeias produtivas globais e, em território sul-mato-grossense, adiciona-se a discussão em torno da Lei das Maquilas $^{2}$, que exige, inevitavelmente, a ampliação da discussão da guerra fiscal para além das fronteiras internacionais e a exportação de oportunidades de investimento e postos de trabalho.

Para coroar o exercício de relacionar as contribuições teóricas acerca do planejamento público, polos de desenvolvimento e a importância da industrialização, destacam-se alguns dados da dinâmica industrial de MS que também sinalizam o sentido das reflexões do próximo objetivo específico, a ser contemplado no subtítulo adiante.

A indústria de Mato Grosso do Sul, de acordo com os dados da Federação das Indústrias do Estado de Mato Grosso do Sul (Fiems) (publicados em 2018), empregava, até 2018, 120 mil trabalhadores e contribuía com 1,2\% da força de trabalho da indústria nacional. E, ainda, o setor industrial possuía 6.149 estabelecimentos com a seguinte distribuição:

Tabela 1. Tipo empresarial das indústrias de MS

\begin{tabular}{|l|c|c|c|c|c|}
\hline Tipo/tamanho & $\begin{array}{c}\mathbf{N}^{\mathbf{0}} \text { de } \\
\text { Funcionários }\end{array}$ & $\begin{array}{c}\mathbf{N}^{\mathbf{0}} \text { de } \\
\text { Empresas }\end{array}$ & $\begin{array}{c}\text { Participação } \\
\text { no total de } \\
\text { industrias } \\
(\boldsymbol{\%})\end{array}$ & $\begin{array}{c}\mathbf{N}^{\mathbf{0}} \text { de } \\
\text { Empregados }\end{array}$ & $\begin{array}{c}\text { Participação no } \\
\text { total de } \\
\text { emprego } \\
\text { industrial (\%) }\end{array}$ \\
\hline Microempresa & 1 a 9 & 4.785 & 78 & 17.024 & 14 \\
\hline Pequena & 10 a 49 & 1.047 & 17 & 19.477 & 16 \\
\hline Média & 50 a 249 & 235 & 4 & 23.154 & 19 \\
\hline Grande & 250 ou mais & 82 & 1 & 60.363 & 50 \\
\hline
\end{tabular}

Fonte: Fiems, 2018.

\footnotetext{
${ }^{2}$ Sobre esse assunto sugere-se a leitura de: Godoy, Vivian Leticia Aguero. Novos Espaços Industriais: a Lei de Maquila e a dinâmica produtiva no território fronteiriço de Ponta Porã (Brasil) e Pedro Juan Caballero (Paraguai). (Dissertação de Mestrado). Ponta Porã: Universidade Estadual de Mato Gross do Sul, 2020 .
}

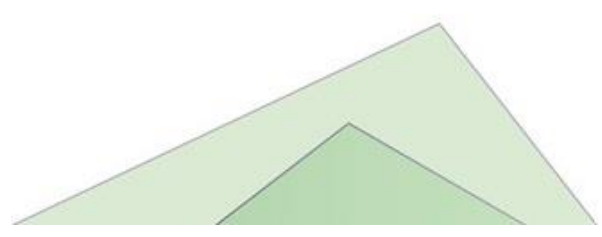


A Tabela 1 indica que as empresas de grande porte, apesar de serem quantitativamente em número menor, geraram praticamente o mesmo número de postos de trabalho que as demais.

A indústria, no período em questão, era responsável por 19,1\% do emprego com carteira assinada, e a média salarial foi de R \$2.236,00 em 2017, gerando um volume monetário de $\mathrm{R}$ \$3,219 bilhões. Isso corresponde a $17 \%$ de tudo que foi pago em salários aos trabalhadores formais do estado. Do ponto de vista da qualificação, $57 \%$ dos trabalhadores da indústria de Mato Grosso do Sul têm ao menos o ensino médio completo. Essa participação aumentou 27 pontos percentuais entre 2007 e 2016.

\section{REGIONALIZAÇÃO INDUSTRIAL DE MATO GROSSO DO SUL}

De acordo com o "Estudo da Dimensão Territorial do Estado de Mato Grosso do Sul: Regiões de Planejamento" da Secretaria de Estado de Meio Ambiente e Desenvolvimento Econômico - Semade $(2015)^{3}$, do ponto de vista do planejamento estadual, a organização do espaço geográfico de Mato Grosso do Sul constituiu uma tentativa de desdobramento das ações de governo dentro de uma divisão territorial que tivesse pontos de convergência estabelecidos por eixos de liderança. Nesse sentido, para estabelecer as regiões de planejamento, foram utilizadas principalmente, a teoria dos polos de desenvolvimento regional, definindo cada região em função do conjunto de municípios e seus laços de inter-relação e de interdependência para com um polo regional.

Por conseguinte, a regionalização proposta para Mato Grosso do Sul está alicerçada em Regiões de Planejamento, que constituem nove polos urbanos regionais

\footnotetext{
${ }^{3}$ No ano de 2017, foi realizada uma reforma administrativa com o objetivo declarado de "reduzir gastos do orçamento estadual". Dessa forma, a Secretaria de Estado de Produção e Agricultura Familiar (Sepaf) e a Secretaria de Estado de Meio Ambiente e Desenvolvimento Econômico (Semade) foram fundidas, passando a se chamar Secretaria de Estado de Meio Ambiente, Desenvolvimento Econômico, Produção e Agricultura Familiar (Semagro). De acordo com o organograma da Semagro, esta dispõe de três Superintendências, sendo uma delas de Indústria, Comércio, Serviços e Turismo.
}

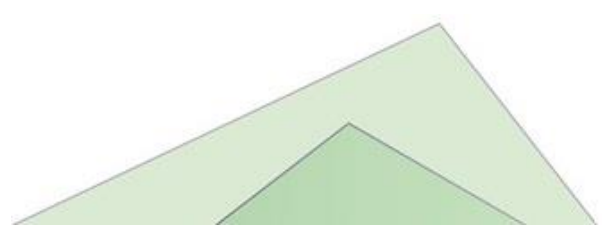


com dimensões diversificadas. Entre eles, o polo regional de Campo Grande é o maior centro urbano e econômico do Estado, exercendo influência sobre as demais regiões, tanto na atração demográfica como no atendimento a demandas de bens e serviços vindas das demais regiões. Como subpolos regionais, aparecem os municípios de Dourados, Corumbá e Três Lagoas, centros urbanos e econômicos com significativa liderança em outras áreas do interior do Estado. Outros cinco polos microrregionais com poder de atração sobre os pequenos centros urbanos são: Naviraí, na Região do Cone - na Região Sul; Ponta Porã na Região Sul - fronteira; Jardim, na Região Sudoeste; São Gabriel do Oeste, na Região Norte; e Nova Andradina, na Região Leste (Semade, 2015). Na Figura 1, estão representadas as Regiões de Planejamento de Mato Grosso do Sul.

Figura 1 - Mapa das Regiões de Planejamento do Estado de Mato Grosso do Sul

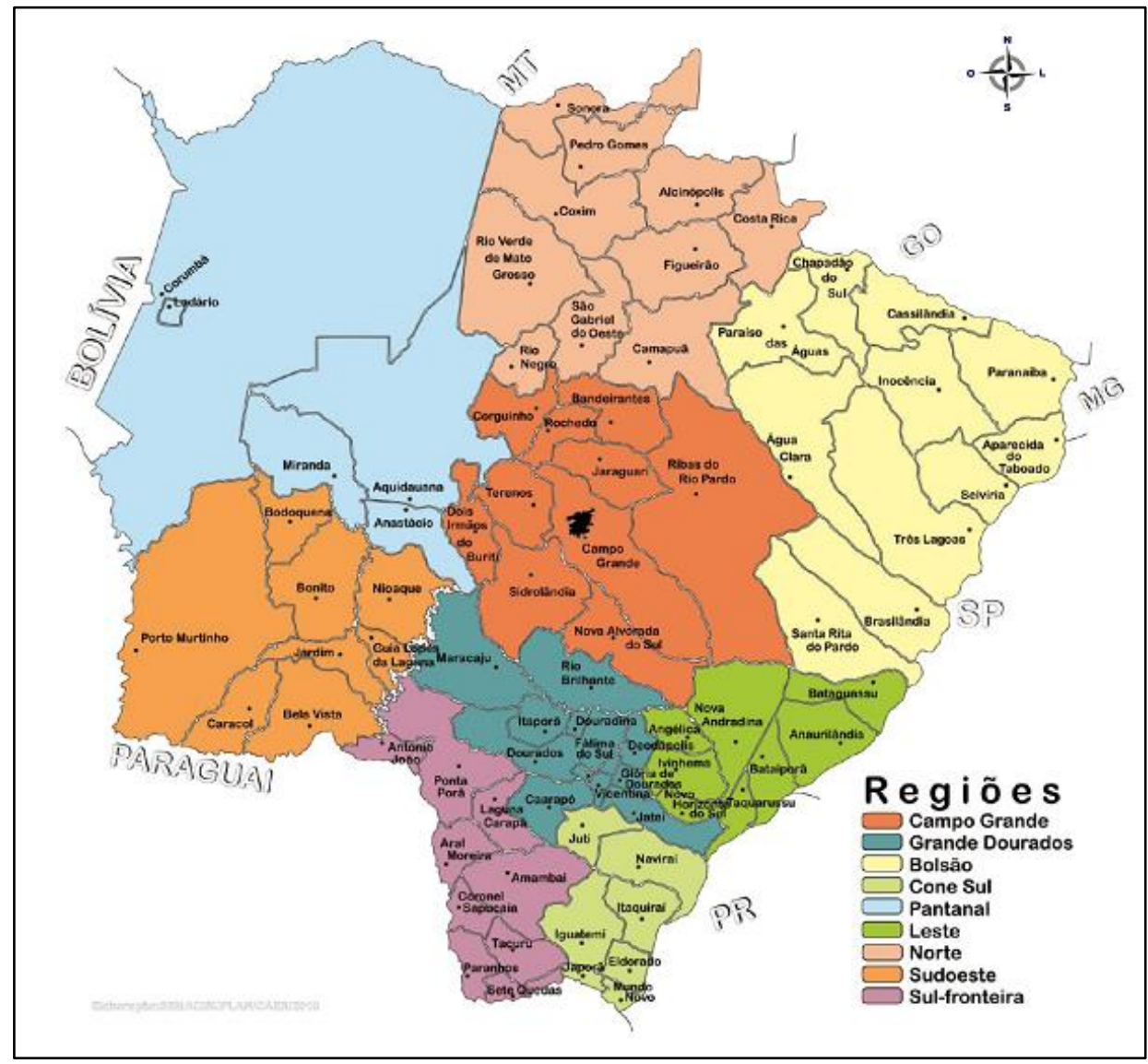

Fonte: Semade (2015). 
A regionalização por meio da distribuição espacial, representada na Figura 1, é utilizada como instrumento de planejamento público pelo governo estadual. Conforme a Semade (2015), a referida regionalização é utilizada como "referência para a implementação de ações e de planos de desenvolvimento do governo do Estado, na busca do desenvolvimento endógeno dos municípios que as compõem, buscando ampliar o bem-estar da sua população com a melhor utilização dos recursos disponíveis" (SEMADE, 2015, p. 17).

Nesse âmbito, conforme o Diagnóstico Socioeconômico de Mato Grosso do Sul/Semade (2015), no território estadual, encontram-se cinco polos de desenvolvimento, conforme representados no Quadro 1.

Quadro 1 - Polos de Desenvolvimento Industrial de Mato Grosso do Sul

\begin{tabular}{|c|c|}
\hline Polo & des \\
\hline Bolsão & $\begin{array}{l}\text { Agroindústria frigorífica e laticínios; indústria de alimentos, têxtil e } \\
\text { confecções; curtumes; moageria de soja (farelo e óleo bruto); embalagem; } \\
\text { indústria de açúcar e álcool; beneficiamento de algodão; gráfica; indústria de } \\
\text { pescado; derivados de plásticos; metalúrgica e siderurgia (ferro-gusa, alumínio } \\
\text { e aço); indústria de madeira; turismo; indústria de calçados; indústria de café; } \\
\text { indústria de papel e celulose. }\end{array}$ \\
\hline $\begin{array}{l}\text { Campo } \\
\text { Grande }\end{array}$ & $\begin{array}{l}\text { Agroindústria frigorífica e laticínios; indústria de alimentos, têxtil e } \\
\text { confecções; metalúrgica; material plástico; curtumes; moagem de soja (farelo e } \\
\text { óleo) refinada; beneficiadora de arroz; gráfica; bens de capital; bebidas e } \\
\text { refrigerantes; compensados e chapas de madeiras; turismo de eventos; ração } \\
\text { animal; sementes de pastagens e cereais; embalagens; indústria de café. }\end{array}$ \\
\hline $\begin{array}{c}\text { Minero - } \\
\text { Siderúrgico }\end{array}$ & $\begin{array}{l}\text { Agroindústria frigorífica e laticínios; indústria de: calcário dolomítico, turismo, } \\
\text { pesca, cerâmica, artefatos de cimento, extração de rochas ornamentais. Na área } \\
\text { que compreende a região de Corumbá, ocorrem agroindústria frigorífica e } \\
\text { laticínios; indústria minero-siderúrgica, cimento e calcário; turismo ecológico } \\
\text { e de pesca; indústria de refrigerantes. }\end{array}$ \\
\hline Norte & $\begin{array}{l}\text { Agroindústria frigorífica e laticínios; indústria de cerâmica; indústria de } \\
\text { alimentos; beneficiadora de algodão; rações; metalúrgica; indústria de açúcar e } \\
\text { álcool. }\end{array}$ \\
\hline Sul & $\begin{array}{l}\text { Agroindústria frigorífica e laticínios; indústrias de alimentos, têxtil e } \\
\text { confecções; curtumes; moageria de soja (farelo e óleo bruto); bebidas; ração } \\
\text { animal; sementes de pastagens e cereais; embalagem; erva-mate; fiação de } \\
\text { algodão; açúcar e álcool; beneficiamento de trigo; gráfica; indústria de pescado; } \\
\text { indústria de biodiesel. }\end{array}$ \\
\hline
\end{tabular}

Fonte: Elaborado pelas autoras a partir de Semade (2015).

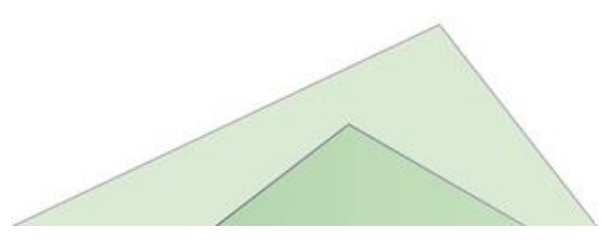


Nesse contexto, o setor industrial de Mato Grosso do Sul está direcionado para o beneficiamento de produtos vindos principalmente do setor agropecuário como grãos, algodão, carnes, leite, couro, cana, mandioca, minérios e madeiras. De acordo com o discurso oficial, a política industrial do estado de Mato Grosso do Sul está voltada para a “implantação e expansão de unidades agroindustriais que utilizem como insumo básico carne, couro, leite, soja, cereais, cana-de-açúcar, madeira da silvicultura, plumas e outros, propiciando agregar mais valor à produção interna" (Semade, 2015, p. 81). Os polos citados no Quadro 1 estão localizados conforme ilustrado na Figura 2.

Figura 2 - Localização dos Polos de Desenvolvimento de Mato Grosso do Sul

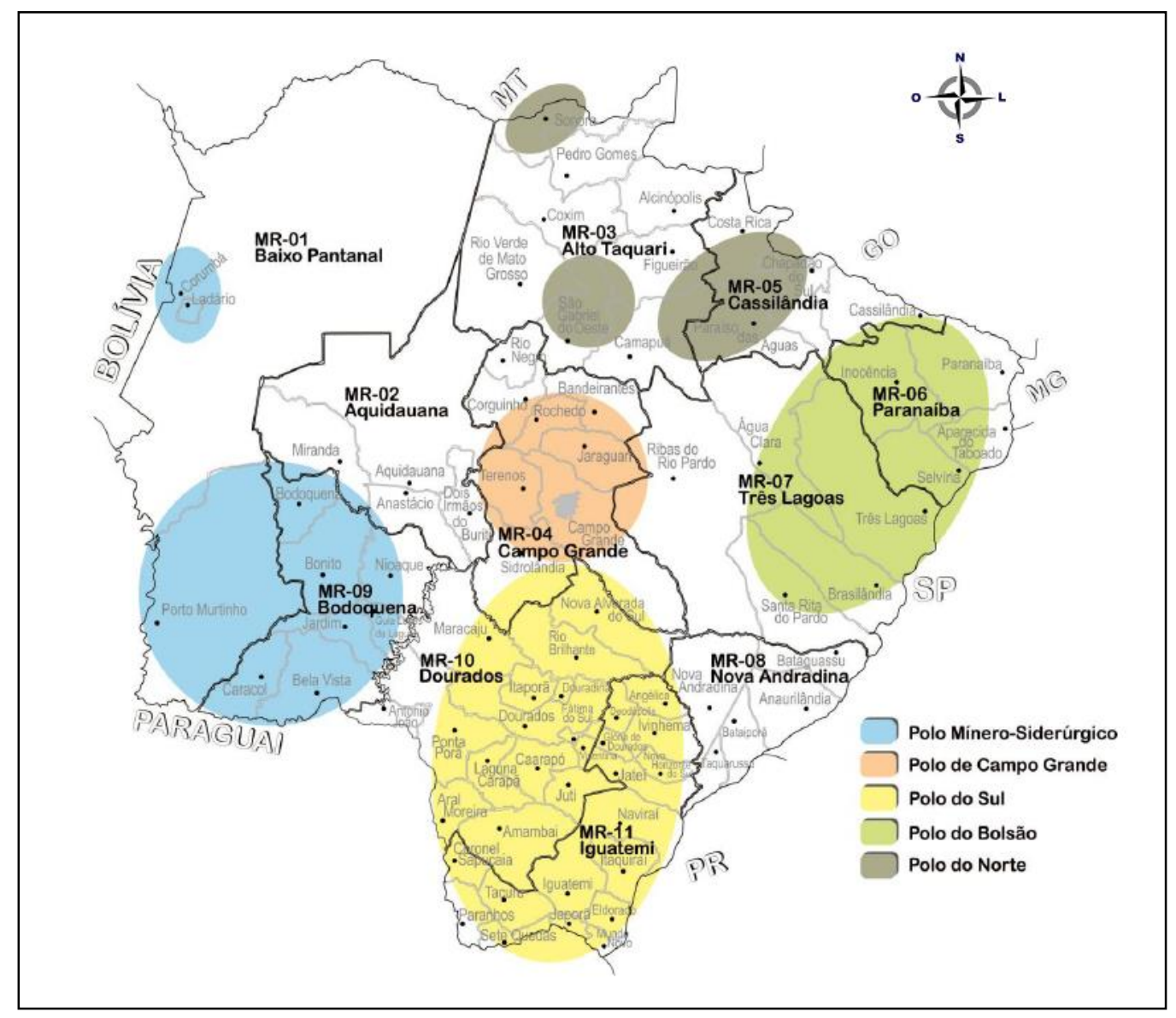

Fonte: Semade, 2015. 
Conforme a Semade (2015), o parque industrial é constituído fundamentalmente por cinco polos (vide Figura 2) que podem ser assim distribuídos: Polo de Campo Grande (liderado pelos municípios de Campo Grande, Terenos e Sidrolândia), Polo do Sul (destaque para os municípios de Dourados, Fátima do Sul, Itaporã e Rio Brilhante), Polo do Bolsão (com maior expressão nos municípios de Três Lagoas, Paranaíba e Aparecida do Taboado), Polo Minero-Siderúrgico (com destaque para os municípios de Corumbá e Ladário) e Polo Norte (norte e porção noroeste da Região do Bolsão).

\section{A POLÍTICA INDUSTRIAL: DOS INCENTIVOS PARA ALGUNS NÚMEROS}

Nas diretrizes do II Plano Nacional de Desenvolvimento (1975-1979) estavam previstas:

[...] a definição e fortalecimento de polos de desenvolvimento, bem como uma política de desconcentração industrial. É nesta conjuntura histórica que há uma intensificação na implantação de distritos industriais pelo território nacional, entre os quais incluem-se os de Campo Grande, Dourados, Três Lagoas e Corumbá, no então Mato Grosso, hoje Mato Grosso do Sul (SOUZA, 2008, p. $15)$.

A partir da divisão do território mato-grossense, por meio da Lei Complementar No 31, de 11 de outubro de 1977, o Poder Executivo federal também institui no Artigo 38 dessa lei, a criação a partir do ano de 1979, dos programas especiais de desenvolvimento para as Unidades da Federação de Mato Grosso e Mato Grosso do Sul, com duração de 10 (dez) anos (1979-1988), propiciando apoio financeiro aos governos dos dois estados, inclusive quanto a despesas correntes. No Mato Grosso do Sul, o programa foi intitulado Programa Especial de Desenvolvimento de Mato Grosso do Sul (Prosul) e, no Mato Grosso, Programa Especial de Desenvolvimento de Mato Grosso (Promat). De acordo com Abreu (2001, p. 238), “o Promat e o Prosul, apesar de terem tido pouca expressão, já que enfrentaram o período de alta dos juros e cortes dos recursos públicos (1979-1984), traçaram o perfil das políticas de desenvolvimento do espaço-matogrossense, do Norte e do $\operatorname{Sul}(\ldots) "$.

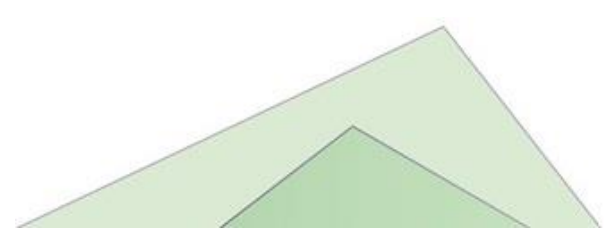


Especificamente, sobre a política industrial de Mato Grosso do Sul, ao longo do tempo, algumas leis foram editadas, alteradas e revogadas. As referidas leis regulamentaram a política industrial, que se fundamenta notadamente na concessão de benefícios fiscais para a instalação ou ampliação de indústrias. No Quadro 2, estão relacionadas as leis estaduais criadas atinentes à política industrial a partir da década de 1980, época em que foram publicadas as primeiras leis.

\begin{tabular}{|c|c|c|}
\hline \multicolumn{3}{|c|}{ Quadro 2 - Legislações atinentes à Política Industrial de MS } \\
\hline Lei & Disposição & Obs. \\
\hline $\begin{array}{l}\text { Lei } \mathrm{N}^{\circ} 440 \text {, de } 21 \text { de março } \\
\text { de } 1984\end{array}$ & $\begin{array}{l}\text { Cria o Conselho de Desenvolvimento Industrial do } \\
\text { Estado de Mato Grosso do Sul e concede os incentivos } \\
\text { que menciona. }\end{array}$ & Revogada \\
\hline $\begin{array}{l}\text { Lei } N^{\circ} 444 \text {, de } 13 \text { de abril } \\
\text { de } 1984\end{array}$ & $\begin{array}{l}\text { Altera e acrescenta dispositivos ao artigo } 1^{\circ} \text { e } 6^{\circ} \text { da Lei } \\
n^{\circ} 440 \text {, de } 21 \text { de março de } 1984 \text {. }\end{array}$ & Revogada \\
\hline $\begin{array}{l}\text { Lei } \mathrm{N}^{\circ} 701 \text {, de } 06 \text { de março } \\
\text { de } 1987\end{array}$ & $\begin{array}{l}\text { Dispõe sobre a política de desenvolvimento da atividade } \\
\text { industrial no estado de Mato Grosso do Sul. }\end{array}$ & Revogada \\
\hline $\begin{array}{l}\text { Lei } \mathrm{N}^{\mathrm{o}} 1.239 \text {, de } 18 \text { de } \\
\text { dezembro de } 1991\end{array}$ & $\begin{array}{l}\text { Reformula a política de desenvolvimento industrial do } \\
\text { estado de Mato Grosso do Sul e dá outras providências. }\end{array}$ & Alterada \\
\hline $\begin{array}{l}\text { Lei } \mathrm{N}^{\circ} 1.798 \text {, de } 10 \text { de } \\
\text { dezembro de } 1997\end{array}$ & $\begin{array}{l}\text { Institui o Programa "Ações para o Desenvolvimento de } \\
\text { Mato Grosso do Sul" em complementação à política de } \\
\text { desenvolvimento industrial do estado e dá outras } \\
\text { providências. }\end{array}$ & Revogada \\
\hline $\begin{array}{l}\text { Lei } N^{\circ} 2.127 \text {, de } 24 \text { de julho } \\
\text { de } 2000\end{array}$ & $\begin{array}{l}\text { Estabelece normas relativas à política de } \\
\text { Desenvolvimento Industrial; prorroga prazo de vigência } \\
\text { da Lei de Incentivo Industrial, e dá outras providências. }\end{array}$ & Revogada \\
\hline $\begin{array}{l}\text { Lei } \mathrm{N}^{\mathrm{o}} 2.183 \text {, de } 14 \text { de } \\
\text { dezembro de } 2000\end{array}$ & $\begin{array}{l}\text { Altera redação de dispositivos da Lei no } 1.239 \text {, de } 18 \text { de } \\
\text { dezembro de } 1991 .\end{array}$ & Vigente \\
\hline $\begin{array}{l}\text { Lei Complementar } \mathrm{N}^{\circ} 093 \text {, } \\
\text { de } 05 \text { de novembro de } 2001 \\
\text { (e alterações) }\end{array}$ & $\begin{array}{l}\text { Institui o Programa Estadual de Fomento à } \\
\text { Industrialização, ao Trabalho, ao Emprego e à Renda } \\
\text { (MS-Empreendedor) e dá outras providências. }\end{array}$ & Vigente \\
\hline $\begin{array}{l}\text { Lei } \mathrm{N}^{\circ} 4.049 \text {, de } 30 \text { de } \\
\text { junho de } 2011\end{array}$ & $\begin{array}{l}\text { Dispõe sobre o Programa Estadual de Desenvolvimento } \\
\text { Industrial MS Forte-Indústria (MS-Forte). }\end{array}$ & Vigente \\
\hline $\begin{array}{l}\text { Lei } \mathrm{n}^{\circ} .5 .039 \text {, de } 8 \text { de } \\
\text { agosto de } 2017\end{array}$ & $\begin{array}{l}\text { Dispõe sobre a instituição ou a prorrogação de incentivos } \\
\text { e de benefícios fiscais ou financeiro-fiscais concedidos } \\
\text { ou a serem concedidos a estabelecimentos de qualquer } \\
\text { natureza, relativos ao ICMS, mediante ou com base em } \\
\text { leis e em outros atos do Poder Executivo. }\end{array}$ & Vigente \\
\hline
\end{tabular}

Fonte: Assembleia Legislativa de MS. Acesso em: 26. Out. 2017.

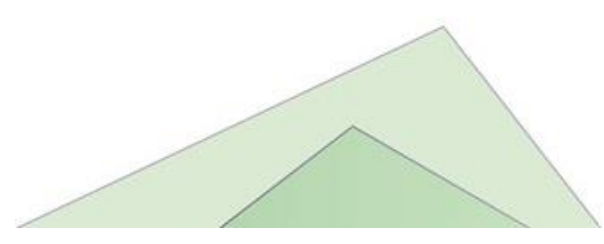


A política industrial sul-mato-grossense continua baseada na concessão de incentivos fiscais para a atração de indústrias. Conforme a Semagro, dispõe-se de incentivos federais, estaduais e municipais visando a industrialização do estado. A partir da política industrial de fomento às empresas, o estado tem por objetivos: estimular a transformação dos produtos primários e recursos naturais; ampliar a base produtiva industrial e sua interiorização; incentivar a instalação de novas indústrias detentoras de tecnologia avançada; dar maior competitividade ao Parque Industrial existente; verticalizar, diversificar e internalizar valor; e gerar emprego e renda à população.

Em se tratando dos incentivos de crédito federais, além das linhas de créditos tradicionais oferecidas por instituições bancárias (BNDES Automático, Finame e Proger $)^{4}$, o Mato Grosso Sul detém como linha de fomento empresarial o Fundo Constitucional de Financiamento do Centro-Oeste (FCO), criado pela Lei 7.827, de 27 de setembro de 1989, que regulamentou o art. 159, inciso I, alínea "c", da Constituição Federal de 1988, e tem por objetivo contribuir para o desenvolvimento econômico e social da região, mediante a execução de programas de financiamento aos setores produtivos, em consonância com o Plano Regional de Desenvolvimento.

A área de abrangência do FCO está restrita à Região Centro-Oeste, integrada pelos estados de Goiás, Mato Grosso e Mato Grosso do Sul e pelo Distrito Federal. As empresas e os produtores rurais podem solicitar empréstimos de até R \$ 4,8 milhões excepcionalmente poderá alcançar até $\mathrm{R} \$ 40$ milhões. O objetivo governamental com o FCO é incrementar o desenvolvimento regional. O prazo de pagamento para investimento fixo é de até 12 anos, incluído o período de carência de até 3 anos. Para capital de giro associado, o prazo é de até 3 anos, incluído o período de carência de até 1 ano.

\footnotetext{
4 Banco Nacional de Desenvolvimento Econômico e Social (BNDES); Finame é um financiamento do BNDES feito por intermédio de instituições financeiras credenciadas para produção e aquisição de máquinas e equipamentos novos de fabricação nacional para empresas que estejam credenciadas no BNDES; Proger é o programa instituído pelo Ministério do Trabalho e Emprego e pelo Conselho Deliberativo do Fundo de Amparo ao Trabalhador (Codefat), cujo objetivo é financiar projetos de investimentos com capital de giro associado, que visem geração de emprego e renda.
}




De acordo com o Relatório de Gestão do FCO (2015), os financiamentos com recursos do Fundo são implementados no âmbito de dois programas. Um é o FCO Empresarial, que tem como público-alvo as pessoas jurídicas de direito privado que se dedicam à atividade produtiva nos setores industrial, agroindustrial, mineral, turístico, comercial, de serviços e de infraestrutura econômica, inclusive empresas públicas não dependentes de transferências financeiras do Poder Público. O outro programa é o FCO Rural, destinado a produtores rurais, na condição de pessoas físicas e jurídicas, a cooperativas de produção e a associações que se dedicam à atividade produtiva no setor rural.

Especificamente de natureza estadual, os incentivos correspondem ao Programa MS-Empreendedor, criado pela Lei Complementar $n^{\circ} 93$ de 05 de novembro de 2001 e regulamentado pelo Decreto $\mathrm{n}^{\mathrm{o}}$. 10.604, de 21 de dezembro de 2001, que instituiu o Programa Estadual de Fomento à Industrialização, ao Trabalho, ao Emprego e à Renda, denominado de (MS-Empreendedor). Esse programa dispõe sobre a concessão de benefícios ou incentivos fiscais, financeiro-fiscais ou extrafiscais como instrumentos de política de fomento à industrialização e à circulação de bens econômicos em seu território.

De acordo com a referida Lei, os benefícios ou incentivos fiscais concedidos às indústrias que se instalarem ou ampliarem suas instalações são de até 67\% do ICMS devido, pelo prazo de até 15 anos, prorrogável por igual período, conforme perfil do empreendimento. O programa prevê a possibilidade de: dispensa do pagamento do ICMS incidente sobre as entradas interestaduais ou sobre a importação de máquinas e equipamentos, destinados ao ativo fixo da empresa, e diferimento do ICMS incidente sobre importações de matérias-primas.

No ano de 2011, o governo estadual editou a Lei $n^{\circ} 4.049$ de 30 de junho, que instituiu o Programa Estadual de Desenvolvimento Industrial MS Forte-Indústria, e manteve os programas de incentivos vigentes à época. Conforme o Art. $2^{\circ}$ da Lei em questão, os benefícios e incentivos fiscais a serem concedidos, constituíam instrumentos

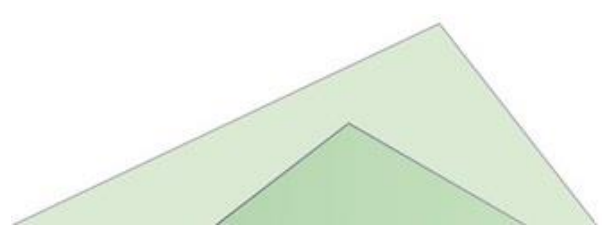


de política fiscal ou de fomento à industrialização e à circulação de bens econômicos em seu território, visando a alcançar os seguintes objetivos governamentais (Quadro 3):

Quadro 3 - Objetivos Governamentais do Programa Estadual de Desenvolvimento Industrial MS Forte-Indústria

\begin{tabular}{|c|}
\hline Objetivos Governamentais do MS Forte-Indústria \\
\hline $\begin{array}{l}\text { I - a instalação de novas empresas, a ampliação, a modernização, a reativação ou a realocação } \\
\text { das existentes, objetivando a interiorização dos empreendimentos econômicos produtivos e o } \\
\text { aproveitamento das potencialidades econômicas regionais }\end{array}$ \\
\hline $\begin{array}{l}\text { II - a transformação de produtos primários em produtos industrializados, visando a favorecer } \\
\text { a integração e a verticalização das cadeias produtivas e a agregação de valores a esses bens; }\end{array}$ \\
\hline $\begin{array}{l}\text { III - a diversificação das bases produtiva e circulatória de bens e serviços, com vista a } \\
\text { dinamizar a economia e a propiciar a manutenção e a geração de novos empregos estáveis, } \\
\text { bem como a melhor distribuição dos bens econômicos, com o consequente aumento } \\
\text { generalizado da arrecadação de tributos; }\end{array}$ \\
\hline $\begin{array}{l}\text { IV - o fornecimento dos meios ao seu alcance para que as empresas locais possam ser mais } \\
\text { competitivas no mercado. }\end{array}$ \\
\hline
\end{tabular}

Fonte: Elaborado pelas autoras a partir da Lei no 4.049 de 30 de junho de 2011.

Em 2017, o governador estadual editou a Lei no 5.039 (de 8 de agosto de 2017), que dispõe sobre a instituição ou a prorrogação de incentivos e de benefícios fiscais ou financeiro-fiscais concedidos ou a serem concedidos a estabelecimentos de qualquer natureza, relativos ao ICMS, mediante ou com base em leis e em outros atos do Poder Executivo. Sobre o prazo de concessão dos incentivos e benefícios fiscais, a referida Lei estabelece que:

Art. $1^{\circ}$ O Poder Executivo fica autorizado a instituir ou a prorrogar, até 31 de
dezembro de 2035 , incentivos e benefícios fiscais ou financeiro-fiscais
concedidos ou a serem concedidos a estabelecimentos de qualquer natureza,
mediante ou com base na Lei Complementar $\mathrm{n}^{\circ}$ 93, de 5 de novembro de 2001 ,
e na Lei $\mathrm{n}^{\circ} 4.049$, de 30 de junho de 2011 , ou em outras leis, decretos,
resoluções e demais normas do Poder Executivo Estadual, de toda e qualquer
atividade, em relação ao Imposto sobre Operações relativas à Circulação de
Mercadorias e sobre Prestações de Serviços de Transporte Interestadual e
Intermunicipal e de Comunicação (ICMS) (MATO GROSSO DO SUL,
2017).

Do ponto de vista local, os municípios detêm políticas diferenciadas para atração de indústrias. Alguns benefícios que podem ser deferidos são: doação de áreas em 
distritos industriais; terraplanagem; isenção de Impostos Predial Territorial Urbano IPTU e Imposto Sobre Serviços - ISS; e capacitação de mão de obra.

Agora, vejamos como estes incentivos se materializaram nos dados industriais.

No intuito de ampliar o número de indústrias instaladas, o estado de Mato Grosso do Sul (como foi abordado) se utiliza de políticas e mecanismos de incentivo para atraílas. De acordo com dados disponibilizados pela Semade, no período de 2010 a 2015, 406 indústrias receberam incentivos para a implantação ou ampliação de suas plantas industriais. Neste período, as indústrias que receberam incentivos fiscais geraram um total de 52.824 empregos $^{5}$.

Dentre os municípios do estado que mais tiveram indústrias incentivadas no referido período, têm-se respectivamente os municípios de Campo Grande, Três Lagoas, Paranaíba, Dourados, Aparecida do Taboado, Cassilândia, Terenos, Bataguassu, Naviraí, São Gabriel do Oeste, Corumbá, Nova Andradina, Sidrolândia e Porto Murtinho. Os demais municípios do estado tiveram entre 5 (cinco) e 1 (uma) indústria incentivada cada um, totalizando 81 indústrias com geração de 13.299 empregos. Veja no Gráfico 1, os municípios que mais tiveram empresas incentivadas e respectivamente o número de empregos gerados.

\footnotetext{
${ }^{5}$ Com referência aos dados sobre empresas incentivadas e geração de empregos, esclarece-se que o recorte temporal utilizado (2010 a 2015) ocorreu em virtude da disponibilização na época, somente desse período pela Secretaria de Estado de Meio Ambiente e Desenvolvimento Econômico (Semade).
}

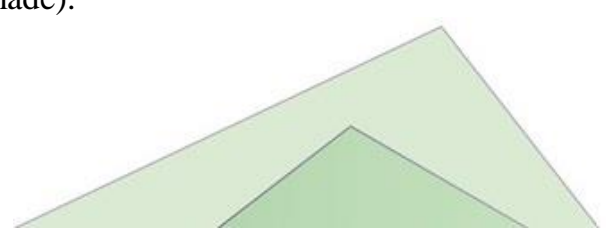


Gráfico 1 - Quantitativo de Indústrias beneficiadas e empregos gerados por municípios de MS - 2010 a 2015

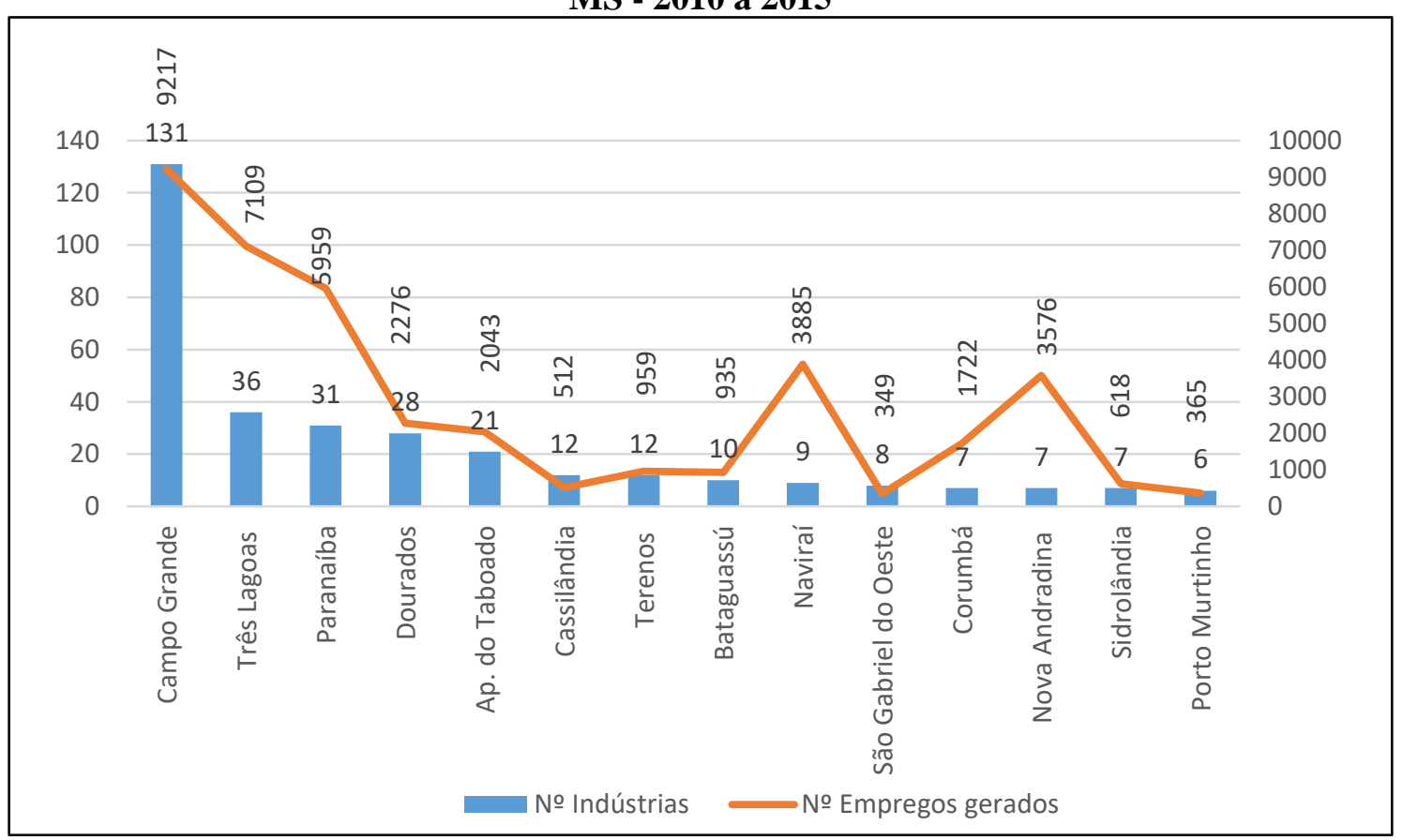

Fonte: Elaborado pelas autoras a partir de Semade-MS (2016).

$\mathrm{Na}$ Tabela 2, têm-se alguns dados dos principais setores da Indústria em Mato Grosso do Sul, como número de empresas, de trabalhadores e a participação de cada setor no valor bruto da indústria do estado.

Os dados apresentados de forma comparativa para os anos de 2016 e 2018 revelam a influência de setores da indústria ligados ao agronegócio ${ }^{6}$ na economia de Mato Grosso do Sul. Em 2016, o setor frigorífico e de produtos de carne aparece em primeiro lugar, com uma participação de 39,20\% no valor bruto da indústria de MS. Em segundo lugar, está o setor metalmecânica com participação de 10,8\%. Na sequência, destacam-se os segmentos agro energético com 10,3\% e de construção civil com 7,3\%. Os setores da indústria que geraram maior número de empregos foram o da construção civil (26.107), frigorífico e de produtos de carne (23.560) e agro energético (21.121). Em 2018, o

\footnotetext{
6 “'(...) o uso corrente do termo 'agronegócio', no Brasil, expressa - ou deseja expressar - as atividades agropecuárias que utilizam técnicas de produção intensiva (mecanização e química) e de escala, o que gera aumento da produção e da produtividade" (SAUER, 2008, p. 16).
}

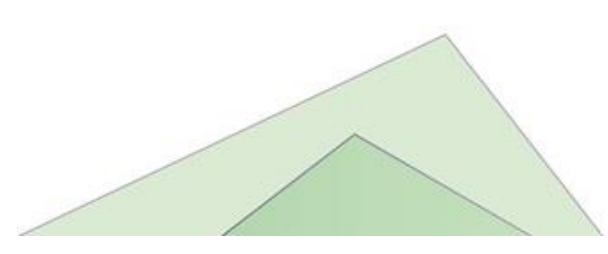


primeiro lugar também é ocupado pelo setor frigorífico e de produtos de carne $(35,7 \%)$, com uma queda de 3,5\% na participação em relação ao ano de 2016, contudo, o segundo lugar passa a ser ocupado pelo setor agro energético $(14,1 \%)$ e a terceira e quarta colocação em participação no valor bruto industrial são ocupadas pelos segmentos de alimentos e bebidas $(9,7 \%)$ e papel e celulose $(8,9 \%)$.

Tabela 2 - Principais Setores da Indústria em Mato Grosso do Sul (2016 e 2018)

\begin{tabular}{|c|c|c|c|c|c|c|c|c|}
\hline $\begin{array}{l}\text { Setores da } \\
\text { Indústria }\end{array}$ & $\begin{array}{l}\text { Partic. no } \\
\text { valor } \\
\text { bruto da } \\
\text { Indústria } \\
\text { em MS } \\
2016(\%)\end{array}$ & $\begin{array}{l}\text { Partic. no } \\
\text { valor } \\
\text { bruto da } \\
\text { Indústria } \\
\text { em MS } \\
2018(\%)\end{array}$ & $\begin{array}{c}\mathrm{N}^{\circ} \mathrm{de} \\
\text { empresas } \\
(2016)\end{array}$ & $\begin{array}{c}\mathrm{N}^{\circ} \text { de } \\
\text { empresas } \\
(2018)\end{array}$ & $\begin{array}{c}\mathrm{N}^{\circ} \text { de } \\
\text { trabalha- } \\
\text { dores } \\
(2016)\end{array}$ & $\begin{array}{c}\mathrm{N}^{\circ} \text { de } \\
\text { trabalha- } \\
\text { dores } \\
(2018)\end{array}$ & $\begin{array}{c}\text { Salário } \\
\text { médio } \\
(\text { em R\$) } \\
(2018)\end{array}$ & $\begin{array}{c}\text { Massa } \\
\text { salarial } \\
\text { (em } \\
\text { milhões } \\
\text { R\$) } \\
(2018)\end{array}$ \\
\hline $\begin{array}{l}\text { Frigorífica e de } \\
\text { Produtos de } \\
\text { Carne }\end{array}$ & 39,2 & 35,7 & 134 & 112 & 23.560 & 25.899 & $1.729,00$ & 537,4 \\
\hline Metalmecânica & 10,8 & 8,5 & 964 & 873 & 7.145 & 7.157 & $1.920,00$ & 164,9 \\
\hline Agro energética & 10,3 & 14,1 & 22 & 22 & $21.121 *$ & 18.785 & $2.798,00$ & 630,7 \\
\hline $\begin{array}{l}\text { Construção } \\
\text { Civil }\end{array}$ & 7,3 & 6,4 & 3.054 & 2.182 & 26.107 & 21.667 & $1.882,00$ & 489,3 \\
\hline $\begin{array}{l}\text { Papel e } \\
\text { Celulose }\end{array}$ & 6,4 & 8,9 & 03 & 26 & $3.564 * *$ & 3.940 & 4.621,00 & 218,5 \\
\hline $\begin{array}{l}\text { Alimentos e } \\
\text { Bebidas }\end{array}$ & 6,3 & 9,7 & 946 & 881 & 10.738 & 11.268 & $1.791,00$ & 242,2 \\
\hline $\begin{array}{l}\text { Têxtil, } \\
\text { Confecção e } \\
\text { Vestuário } \\
\end{array}$ & 5,6 & 3,2 & 397 & 303 & 6.499 & 5.880 & $1.358,00$ & 95,8 \\
\hline Extrativa & 4,5 & 2,8 & 123 & 111 & 2.634 & 2.443 & $2.703,00$ & 79,2 \\
\hline $\begin{array}{l}\text { Química, } \\
\text { Produtos } \\
\text { Veterinários e } \\
\text { Farmacêuticos }\end{array}$ & 2,9 & 3,5 & 190 & 68 & 3.409 & 1.435 & $2.967,00$ & 51,1 \\
\hline $\begin{array}{l}\text { Produtos } \\
\text { Minerais não } \\
\text { Metálicos } \\
\end{array}$ & 2,1 & 1,8 & 411 & 352 & 4.143 & 3.506 & $1.772,00$ & 74,6 \\
\hline $\begin{array}{l}\text { Produtos } \\
\text { Plásticos }\end{array}$ & 1,6 & 1,4 & 95 & 54 & 2.365 & 1.944 & $1.901,00$ & 44,3 \\
\hline $\begin{array}{l}\text { Beneficiamento } \\
\text { do Couro }\end{array}$ & 1,5 & 2,1 & 41 & 19 & 1.531 & 1.608 & $1.890,00$ & 36,5 \\
\hline Calçados & 0,6 & 0,9 & 25 & 22 & 1.879 & 1.703 & $1.246,00$ & 25,5 \\
\hline $\begin{array}{l}\text { Madeira e } \\
\text { Mobiliário }\end{array}$ & 0,6 & 0,6 & 423 & 372 & 2.581 & 2.702 & $1.488,00$ & 48,2 \\
\hline Gráfica & 0,3 & 0,2 & 358 & 306 & 1.756 & 1.279 & $1.597,00$ & 24,5 \\
\hline
\end{tabular}

*Somente nas Usinas/ ** Sem a parte florestal/

Fonte: Elaborado pelas autoras a partir de Fiems (2016, 2018). 
Um diagnóstico que se destaca é a queda de 20\% (1.483) no número total de empresas: em 2016, eram 7.186 empresas e, em 2018, contabilizaram-se 5.703. Ressaltase que dos 15 segmentos analisados, apenas dois não registraram queda no número, sendo que o agro energético apresentou o mesmo número (22 unidades industriais), e o de Papel e Celulose ampliou de 3 para 26 unidades na contramão da tendência dos demais 13 segmentos.

Essa diminuição se traduziu em 7.816 postos de trabalho a menos, correspondendo a uma queda na ordem de 6,5\% de trabalhadores empregados na indústria. A análise de cada segmento indica que apenas cinco registraram aumento no número de postos de trabalho (frigoríficos, papel e celulose, alimentos e bebidas, beneficiamento de couro, madeira e mobiliário). Apenas o setor metalmecânica não indicou modificações significativas. Os demais nove setores registraram diminuição do contingente de mão-de-obra empregada.

Os segmentos que geram a maior parte dos postos de trabalho são os que também apresentam maior participação no valor bruto (com exceção da construção civil), e o maior valor médio salarial é pago pelo setor de papel e celulose, seguido pelo ramo químico, produtos veterinários e farmacêuticos, agro energético e metalmecânico.

Os maiores volumes em termos de massa salarial correspondem à indústria agro energética, frigoríficos, construção civil e papel e celulose.

O único setor que ocupa alguma posição de liderança nos números apresentados e que não está diretamente relacionado ao agronegócio é a construção civil.

\section{CONSIDERAÇÕES FINAIS}

Este artigo teve por objetivo apreender a realidade industrial de Mato Grosso do Sul por meio da política de incentivos fiscais. Para contemplar tal proposta, foi necessário identificar as diferentes possibilidades de incentivos fiscais. Esta realidade só pode ser

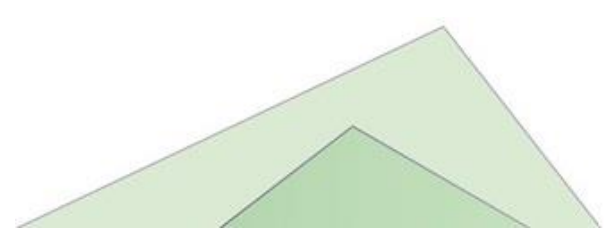


compreendida à luz da dinâmica industrial brasileira, que, historicamente, contou com o papel ativo do Estado por meio do planejamento público.

Em pleno século XXI, o direcionamento estatal (leia-se incentivos) continua sendo justificado uma vez que a lógica empresarial está pautada na lucratividade crescente e custos decrescentes. Nessa perspectiva, os territórios (por meio de suas instâncias públicas) disputam os investimentos privados no intuito de gerar empregos e dinamismo econômico e, em troca, fazem, especialmente em nível municipal, a renúncia fiscal.

A partir da abordagem sobre a política industrial de Mato Grosso do Sul, verificou-se que ela é baseada principalmente na concessão de benefícios fiscais para a ampliação e instalação de indústrias. Essa unidade federativa dispõe ainda de linhas de financiamento de origem federal direcionados à indústria, que consistem no FCO Empresarial, FAT Integrar Empresarial e linhas de crédito do BNDES. Além disso, possui benefícios no âmbito municipal.

Com relação à instituição responsável pela execução da política industrial em Mato Grosso do Sul, ela é executada pela Semagro, uma Secretaria de Estado que agrupa um conjunto de pastas (Produção, Desenvolvimento Econômico, Meio Ambiente e Agricultura Familiar) e tem no seu organograma a Superintendência de Indústria, Comércio, Serviços e Turismo, que se constitui no órgão responsável pelo setor industrial.

A dinâmica industrial de Mato Grosso do Sul pode ser apreendida a partir da lógica da industrialização das matérias-primas produzidas regionalmente, portanto, não pressupõe mudança estrutural do ponto de vista produtivo, muito embora essa mudança esteja prevista no corpo dos documentos oficiais.

A dependência, em termos quantitativos, no que se refere à geração de receitas tributárias, renda e emprego em poucos segmentos oligopolizados reverbera em vulnerabilidades e fragilidades diante da conjuntura econômica internacional e nacional, marcadamente instável na segunda década do século XXI.




Por fim, é possível afirmar que a desconcentração industrial brasileira e o papel desempenhado pelo território sul-mato-grossense respondem a uma lógica pautada na busca pelo crescimento econômico (ou seja, aumento quantitativo da riqueza e não desenvolvimento) e exploração das vantagens competitivas de cada território.

\section{REFERÊNCIAS BIBLIOGRÁFICAS}

ABREU, Silvana de. Planejamento governamental: a SUDECO no espaço matogrossense: contexto, propósitos e contradições. 2001. 323 p. Tese (Doutorado em Geografia) - Faculdade de Filosofia, Letras e Ciências Humanas da Universidade de São Paulo (USP), São Paulo-SP, 2001. Disponível em: <http://www.teses.usp.br/teses/disponiveis/8/8136/tde-28022002-232232/pt-br.php> Acesso em 30. Set. 2016.

AL-MS - Assembleia Legislativa de Mato Grosso do Sul. Legislação Estadual. Disponível em: <http://aacpdappls.net.ms.gov.br/appls/legislacao/secoge/govato.nsf>. Acesso em: 26. Out. 2017.

BRASIL. Constituição (1988). Constituição da República Federativa do Brasil. Disponível em: <http://www.planalto.gov.br/ccivil_03/constituicao/constituicao.htm> Acesso em: 11. Jan. 2017.

BRASIL. Lei Complementar $\mathbf{N}^{\circ} 31$, de 11 de Outubro de 1977. Cria o Estado de Mato Grosso do Sul, e dá outras providências. Disponível em: <http://www.planalto.gov.br/ccivil_03/leis/lcp/Lcp31.htm> Acesso em: 21.07.2018.

BRASIL. II Plano Nacional de Desenvolvimento (1975-1979). Brasília, Presidência da República, setembro de 1974.

DINIZ, Clélio Campolina. A Dinâmica Regional Recente da Economia Brasileira e suas Perspectivas. IPEA, junho de 1995.

FERRAZ, João Carlos; DE PAULA, Germano Mendes; KUPFER, David. Política Industrial. In: David Kupfer; Lia Haguenauer. (Org.). Economia Industrial: fundamentos teóricos e prática no Brasil. Rio de Janeiro: Elsevier, 2002, p. 545-567.

FIEMS - Federação das Indústrias do Estado de Mato Grosso do Sul. <http://www.fiems.com.br/> Acesso em: 01. Out. 2016.

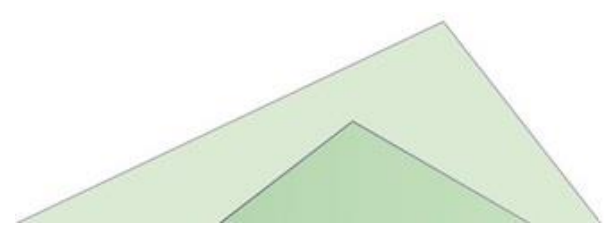


FIEMS - Federação das Indústrias do Estado de Mato Grosso do Sul. Panorama MS Industrial, Perfil e Indicadores 2018. Disponível em: <www.fiems.com.br> Acesso em: 30. Out. 2020..

GODOY, Vivian Leticia Aguero. Novos Espaços Industriais: a Lei de Maquila e a dinâmica produtiva no território fronteiriço de Ponta Porã (Brasil) e Pedro Juan Caballero (Paraguai). (Dissertação de Mestrado). Ponta Porã: Universidade Estadual de Mato Grosso do Sul, 2020.

HOBSBAWM, Eric. Era dos Extremos: o breve século XX (1914 - 1991). Tradução de Marcos Santarrita; Revisão Técnica de Maria Célia Paoli. São Paulo: Companhia das Letras, 1995.

IBGE - Instituto Brasileiro de Geografia e Estatística . Disponível em: <https://www.ibge.gov.br/> Acesso em: 28. Out. 2020.

MATO GROSSO DO SUL. Decreto n 10.604, de 21 de dezembro de 2001. Regulamenta a Lei Complementar $n^{\circ}$ 93, de 5 de novembro de 2001, que institui o Programa Estadual de Fomento à Industrialização, ao Trabalho, ao Emprego e à Renda (MSEMPREENDEDOR), e dá outras providências. Disponível em: <http://aacpdappls.net.ms.gov.br/appls/legislacao/secoge/govato.nsf/1b758e65922af3e9 04256b220050342a/7134368bf39447fc04256bfb001155b8?OpenDocument>. Acesso em: 26. Out. 2017.

MATO GROSSO DO SUL. Lei $\mathbf{n}^{\circ}$ 440, de 21 de março de 1984. Cria o Conselho de Desenvolvimento Industrial do Estado de Mato Grosso do Sul e concede os incentivos que menciona. Disponível em: <http://aacpdappls.net.ms.gov.br/appls/legislacao/secoge/govato.nsf/1b758e65922af3e9 04256b220050342a/8d78ce518255969a04256e450002e8d0?OpenDocument>. Acesso em: 02. Jan. 2018.

MATO GROSSO DO SUL. Lei $\mathbf{n}^{\circ}$ 444, de 13 de abril de 1984. Altera e acrescenta dispositivos ao artigo $1^{\circ}$ e $6^{\circ}$, da Lei $\mathrm{n}^{\circ} 440$, de 21 de março de 1.984. Disponível em: <http://aacpdappls.net.ms.gov.br/appls/legislacao/secoge/govato.nsf/1b758e65922af3e9 04256b220050342a/50ab6ffcb5cbb30404256e450002e8d4?OpenDocument>. Acesso em: 02. Jan. 2018.

MATO GROSSO DO SUL. Lei no 701, de 06 de março de 1987. Dispõe sobre a política de desenvolvimento da atividade industrial no Estado de Mato Grosso do Sul. Disponível em:

<http://aacpdappls.net.ms.gov.br/appls/legislacao/secoge/govato.nsf/448b683bce4ca847 04256c0b00651e9d/6194a4b72aa43d4204256e450002e844?OpenDocument>. Acesso em: 02. Jan. 2018.

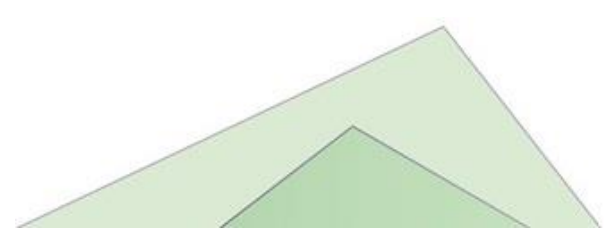


MATO GROSSO DO SUL. Lei $\mathbf{n}^{\mathbf{0}}$ 1.239, de 18 de dezembro de 1991. Reformula a política de desenvolvimento industrial do Estado de Mato Grosso do Sul e dá outras providências.

Disponível

em: <http://aacpdappls.net.ms.gov.br/appls/legislacao/secoge/govato.nsf/448b683bce4ca847 04256c0b00651e9d/c7cd105960e50ed704256e450002ebe2?OpenDocument>. Acesso em: 03. Jan. 2018.

MATO GROSSO DO SUL. Lei $\mathbf{n}^{\mathbf{0}} \mathbf{1 . 7 9 8}$, de 10 de dezembro de 1997. Institui o Programa "Ações para o Desenvolvimento de Mato Grosso do Sul" e dá outras providências. Disponível em: <http://aacpdappls.net.ms.gov.br/appls/legislacao/secoge/govato.nsf/448b683bce4ca847 04256c0b00651e9d/aba8da0f2b582cf204256bfd00676747?OpenDocument >. Acesso em: 03. Jan. 2018.

MATO GROSSO DO SUL. Lei $\mathbf{n}^{0}$ 2.127, de 24 de julho de 2000. Estabelece normas relativas à política de Desenvolvimento Industrial; prorroga prazo de vigência da Lei de Incentivo Industrial, e dá outras providências. Disponível em: <http://aacpdappls.net.ms.gov.br/appls/legislacao/secoge/govato.nsf/1b758e65922af3e9 04256b220050342a/d76eba4c6316791304256bfd0067606d?OpenDocument>. Acesso em: 04. Jan. 2018.

MATO GROSSO DO SUL. Lei $\mathbf{n}^{\mathbf{0}} \mathbf{2 . 1 8 3}$, de 14 de dezembro de 2000. Altera redação de dispositivos da Lei $\mathrm{n}^{\mathrm{o}}$ 1.239, de 18 de dezembro de 1991. Disponível em: <http://aacpdappls.net.ms.gov.br/appls/legislacao/secoge/govato.nsf/1b758e65922af3e9 04256b220050342a/871dba616d283a2b04256bf9005660d5?OpenDocument>. Acesso em: 04. Jan. 2018.

MATO GROSSO DO SUL. Lei Complementar $\mathbf{n}^{\mathbf{0}}$ 93, de 05 de novembro de 2001. Institui o Programa Estadual de Fomento à Industrialização, ao Trabalho, ao Emprego e à Renda (MS-EMPREENDEDOR) e dá outras providências. Disponível em: <http://aacpdappls.net.ms.gov.br/appls/legislacao/secoge/govato.nsf/1b758e65922af3e9 04256b220050342a/3a836f159c1b161904256c000058e57a?OpenDocument>. Acesso em: 26. Out. 2017.

MATO GROSSO DO SUL. Lei $\mathbf{n}^{\mathbf{0}} \mathbf{5 . 0 3 9}$, de 08 de agosto de 2017. Dispõe sobre a instituição ou a prorrogação de incentivos e de benefícios fiscais ou financeiro-fiscais concedidos ou a serem concedidos a estabelecimentos de qualquer natureza, relativos ao ICMS, mediante ou com base em leis e em outros atos do Poder Executivo. Disponível em:

<http://aacpdappls.net.ms.gov.br/appls/legislacao/secoge/govato.nsf/448b683bce4ca847 04256c0b00651e9d/ca715a0f9d4819df0425817600717aff?OpenDocument>. Acesso em: 04. Jan. 2018.

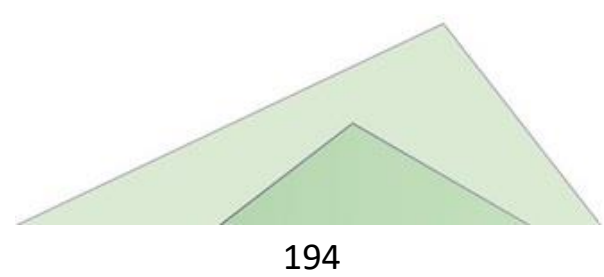


MENDONÇA, Tibério. Processo de Industrialização Brasileira. 2010. Disponível em: <www.tiberiogeo.com.br/texto/TextoUvaIndustriaBrasil.pdf>. Acesso em: 11. Out. 2016.

MINISTÉRIO DA INTEGRAÇÃO NACIONAL. FCO - FUNDO CONSTITUCIONAL DE FINANCIAMENTO DO CENTRO-OESTE. Relatórios de Gestão dos Exercícios 2002-2015. Brasília (DF).

NASCIMENTO, Sidnei Pereira do. Guerra Fiscal: uma avaliação comparativa entre alguns Estados participantes. Economia Aplicada, São Paulo, v. 12, n. 4, p. 677-706, OUTUBRO-DEZEMBRO 2008.

RIBEIRO SILVA, Cristovão Henrique. Política Industrial Brasileira e a Industrialização de Mato Grosso do Sul no Século XXI. 2016. 277 f. Tese (Doutorado em Geografia) - Faculdade de Ciências Humanas da Universidade Federal da Grande Dourados (UFGD), Dourados-MS, 06. Maio. 2016.

SAMPAIO, Leonel de Miranda. Tendências recentes da espacialização das indústrias e serviços em São Paulo/SP e no ABC paulista. Economía, Sociedad y Territorio, v. XV, p. 483-515, 2015.

SANTOS, Milton; SILVEIRA, Maria Laura. O Brasil: território e sociedade no início do século XXI. Rio de Janeiro: Record, 2001. 473 p.

SAUER, Sérgio. Agricultura familiar versus agronegócio: a dinâmica sociopolítica do campo brasileiro. Embrapa Informação Tecnológica, Brasília - DF, 2008.

SEMADE-MS - Secretaria de Estado de Meio Ambiente e Desenvolvimento Econômico de Mato Grosso do Sul. Diagnóstico Socioeconômico de Mato Grosso do Sul 2015. Disponível em: $\quad<$ http://www.semade.ms.gov.br/wpcontent/uploads/sites/20/2015/03/Diagnostico_Socioeconomico_de_MS_20151.pdf>

Acesso em: 03. Fev. 2017.

SEMADE-MS - Secretaria de Estado de Meio Ambiente e Desenvolvimento Econômico de Mato Grosso do Sul. Estudo da Dimensão Territorial do Estado de Mato Grosso do Sul: Regiões de Planejamento. 2015. Disponível em: $<$ http://www.semagro.ms.gov.br/wp-

content/uploads/2017/06/estudo_dimensao_territorial_2015.pdf $>$ Acesso em: 05. Fev. 2017.

SILVA, Ricardo Barbosa da. Concentração e desconcentração industrial: São Paulo é centro industrial do país. 2008. Disponível em: <http://educacao.uol.com.br> Acesso em: 05. Out. 2016.

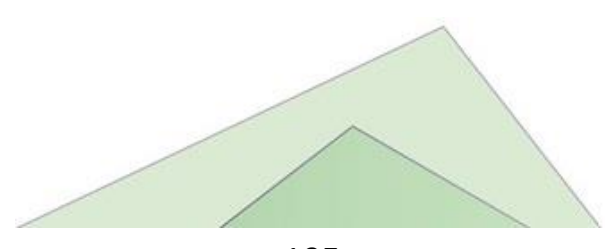


SOUZA, Adauto de Oliveira. Mato Grosso do Sul no contexto dos novos paradigmas de integração e desenvolvimento nacional. Dourados, MS: Editora UFGD, 2008.

SUNKEL, Osvaldo; PAZ, Pedro. El Subdesarrollo Latinoamericano y la Teoria del Desarrollo. México: Siglo Veintiuno, 1970.

Recebido em março de 2020.

Revisado em setembro de 2020.

Aceito para publicação em novembro de 2020. 